УДК 631.41/.445.4:631.811.004.12:631.51/.582

(C) 2012

Примак І. Д., доктор сільськогосподарських наук, професор, Купчик В. І., кандидат сільськогосподарських наук,

Колесник Т. В., здобувач *

Білоцерківський національний аграрний університет

\title{
ЗМІНА АГРОХІМІЧНИХ ВЛАСТИВОСТЕЙ ЧОРНОЗЕМУ ТИПОВОГО ЗА РІЗНИХ СИСТЕМ ОСНОВНОГО ОБРОБІТКУ ГРУНТУ Й УДОБРЕННЯ В ЦЕНТРАЛЬНОМУ ЛІСОСТЕПУ УКРАЇНИ
}

\section{Рецензент - доктор сільськогосподарських наук Г. І. Демидась}

Висвітлено вплив чотирьох систем основного обробітку трунту й удобрення на зміну агрохімічних властивостей чорнозему типового і продуктивності зернопросапної сівозміни. Встановлено статистично достовірне підвищення вмісту гумусу в орному шарі трунту за дві ротаиії сівозміни за тривалого мілкого обробітку і внесення на кожний гектар ріллі 12 т гною $+N_{87} P_{114} K_{114 .}$ У польовій n'ятипільній зернопросапній сівозміні центрального Лісостепу Украӥни рекомендується глибока (2830 см) культурна оранка в одному полі (під повторну кукурудзу, де вноситься гній), а на решті полів мілкий обробіток на 10-12 cм.

Ключові слова: обробіток, удобрення, трунт, агрохімічні властивості, сівозміна, продуктивнiсть

Постановка проблеми. В Україні екологічні наслідки деградації грунтів і погіршення їх родючості особливо загострились у перехідному періоді від державної до ринкової економіки внаслідок використання земель як єдиного засобу існування в умовах виживання за рахунок потенційної родючості грунтів, без компенсації витрат. Однак відомо, що на створення одного сантиметра грунтової товщі природа затрачає близько 100 років, а щоб ії втратити інколи досить і однієї зливи [7]. Нині середньорічні втрати гумусу чорноземів України (основного показника родючості) перевищують 1 т/га, а дегуміфікацією охоплено 39 млн га сільськогосподарських угідь [2]. Родючість староорних грунтів суттєво залежить від характеру їх використання. Інтенсивний механічний обробіток грунту, недостатне внесення добрив - все це може спричинити істотне погіршення якості грунтів. Нині класичний плужний обробіток, у так би мовити, чистому вигляді, в Україні майже ніде не застосовується. Зазвичай це диференційований обробіток, коли під окремі культури здійснюється оранка, диско- вий, плоскорізний або чизельний обробітки на глибину в межах від 6-8 до 40-45 см [8].

Аналіз основних досліджень і публікацій, в яких започатковано розв'язання проблеми. Суперечливість даних стосовно впливу способів, глибини, заходів і засобів механічного обробітку на родючість грунту та продуктивність культур зумовлена не лише недостатнім вивченням, неабиякою складністю та багатогранністю, але й значною різноманітністю грунтово-кліматичних умов, у яких проводилися дослідження [9].

Як свідчить аналіз джерел, вчені дотримуються думки про те, що обробіток грунту в сівозміні повинен бути різноглибинним, за якого чергуються глибокі, середні, мілкі й поверхневі полицеві та безполицеві обробітки $[3,8]$. Площа орних земель в Україні, де оптимальні грунтовотехнологічні умови дають можливість мінімізувати обробіток і навіть повністю відмовитися від нього, становить 2,56 млн га. Це центральний i лівобережний Лісостеп, де домінують чорноземи типові, які відзначаються гармонійним поєднанням чинників, що обумовлюють енергетичну (i, ймовірно, екологічну) вигідність механічного обробітку з одночасними сприятливими екологічними та агрономічними наслідками [5].

Однак питання радикальної мінімізації обробітку грунту залишається невирішеним, оскільки не вивчено досконало агротехнічну, економічну, екологічну, протибур'янову ефективність різних систем обробітку в поєднанні з удобренням, меліоративними та іншими агрозаходами.

Мета досліджень. Встановити оптимальний варіант поєднання системи основного обробітку й удобрення, що забезпечує відтворення агрохімічних показників родючості орного шару грунту за продуктивності зернопросапної сівозміни понад 80 ц/га сухої речовини.

* Керівник-доктор сільськогосподарських наук, професор І. Д. Примак 
Методика досліджень. Дослідження проводили протягом 2002-2011 рр. у стаціонарному польовому досліді на дослідному полі Білоцерківського НАУ. Грунт - чорнозем типовий глибокий малогумусний легкосуглинковий. Повторність досліду - триразова; площа облікової ділянки $-112 \mathrm{~m}^{2}$.

У сівозміні досліджували чотири варіанти основного обробітку (табл. 1) й удобрення. Рівні щорічного внесення добрив на 1га сівозмінної площі становили: нульовий рівень - без добрив, перший -4 т гною $+\mathrm{N}_{29} \mathrm{P}_{38} \mathrm{~K}_{38}$, другий -8 т гною $+\mathrm{N}_{58} \mathrm{P}_{76} \mathrm{~K}_{76}$, третій -12 т гною $+\mathrm{N}_{87} \mathrm{P}_{114} \mathrm{~K}_{114}$.

3 органічних добрив вносили напівперепрілий гній великої рогатої худоби, 3 мінеральних аміачну селітру, простий гранульований суперфосфат і калійну сіль. Оранку здійснювали плугом ПН-4-35, мілкий обробіток на 10-12 см лущильником ПЛ-5-25 і бороною БДВ-3,0, безполицевий - плоскорізом КПГ-2-150.

Агрохімічні властивості грунту визначали за загальноприйнятими методиками: гумус - за I. В. Тюріним, загальний азот - за К'єльдалем, лужногідролізуючий азот - за Корнфілдом, аміачний азот - в одній витяжці із застосуванням реактиву Несслера, нітратний азот - дисульфофеноловим методом, доступний фосфор - методом Чирікова, обмінний калій - на полуменевому фотометрі, pН сольової суспензії - потенціометричним методом, гідролітичну кислотність за Г. Каппеном, суму ввібраних основ - за методом Каппена-Гільковиця, обмінні катіони (Ca i $\mathrm{Mg}$ - трилонометричним методом [1].

Результати досліджень. Вміст загального азоту в орному шарі грунту в 2011 р., порівняно 3 2002 р., на неудобрених ділянках і удобрених нор- мою 4 т/га гною $+\mathrm{N}_{29} \mathrm{P}_{38} \mathrm{~K}_{38}$ зменшився, відповідно, на 4,9 і 2,2 \% - на контрольному варіанті обробітку, 6,8 і 2,9 \% - на другому, 3,6 і 1,4 \% - третьому, 2,9 і $1,1 \%$ - на четвертому варіанті. Цей показник за вказаний період зріс на 0,23 т/га за тривалого дискового лущення і внесення 12 т/га гною + $\mathrm{N}_{87} \mathrm{P}_{114} \mathrm{~K}_{114}$ при $\mathrm{HIP}_{05}$ 0,20 т/га (табл. 2).

3 підвищенням рівня внесених добрив показники обмінної кислотності, суми поглинутих основ і ступеня насиченості грунту основами зменшуються. Так, у 2011 р., порівняно з 2002 р., це зниження за внесення 12 т/га гною + $\mathrm{N}_{87} \mathrm{P}_{114} \mathrm{~K}_{114}$ становило, відповідно: за постійної оранки - 0,34; 3,8 ммоль/100 г і 3,5 \%, плоскорізного обробітку - 0,$72 ; 5,4$ і 5,1 , тривалого лемішного лущення - 0,42; 3,6 і 3,3, тривалого дискового лущення - 0,35; 3,8 ммоль/100 г і 3,5 \%.

У середньому по досліду ці показники за вказаний період досліджень на неудобрених ділянках зменшилися, відповідно, на 0,$15 ; 1,8$ ммоль/100 г і 1,6\%, а за внесення 8 т/га гною + $\mathrm{N}_{58} \mathrm{P}_{76} \mathrm{~K}_{76}$ - на 0,38; 3,4 ммоль/100 г і 3,1 \%.

Під впливом систематичного внесення фізіологічно кислих форм мінеральних добрив спостерігалося підвищення гідролітичної кислотності грунту, зменшення обмінної кислотності, суми поглинутих основ і ступеня насиченості основами, передусім за обробітку плоскорізом. Так, величина гідролітичної кислотності на неудобрених ділянках і удобрених 12 т/га гною + $\mathrm{N}_{87} \mathrm{P}_{114} \mathrm{~K}_{114}$ за 10 років досліджень зросла, відповідно, на 0,16 і 0,43 ммоль $/ 100$ г за постійної оранки, 0,30 і 0,59 - плоскорізного обробітку, 0,18 і 0,46 - тривалого лемішного лущення, 0,21 і 0,46 ммоль/100 г - за тривалого дискового лущення.

\section{1. Схема обробітку трунту під культури зернопросапної сівозміни}

\begin{tabular}{|c|c|c|c|c|c|}
\hline \multirow{3}{*}{ 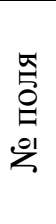 } & \multirow{3}{*}{$\begin{array}{l}\text { Культура } \\
\text { сівозміни }\end{array}$} & \multicolumn{4}{|c|}{ Системи основного обробітку грунту } \\
\hline & & $\begin{array}{c}1 \text { - постійна } \\
\text { оранка (контроль) }\end{array}$ & $\begin{array}{c}2 \text { - постійний } \\
\text { безполицевий } \\
\text { обробіток }\end{array}$ & $\begin{array}{c}3 \text { - тривале } \\
\text { лемішне лущення }\end{array}$ & $\begin{array}{c}4 \text { - тривале } \\
\text { дискове лущення }\end{array}$ \\
\hline & & \multicolumn{4}{|c|}{ глибина (см) і знаряддя обробітку* } \\
\hline 1 & $\begin{array}{c}\text { Однорічні } \\
\text { трави } \\
\end{array}$ & 20 (o.) & 20 (п.) & 10 (п. л.) & 10 (д. б.) \\
\hline 2 & Пшениця озима & 15 (o.) & 15 (п.) & 10 (п. л.) & 10 (д. б.) \\
\hline 3 & $\begin{array}{c}\text { Кукурудза } \\
\text { на зерно }\end{array}$ & 25 (o.) & 25 (п.) & 10 (п. л.) & 10 (д. б.) \\
\hline 4 & $\begin{array}{c}\text { Кукурудза } \\
\text { на зерно }\end{array}$ & 28 (o.) & 28 (п.) & 28 (o.) & 28 (o.) \\
\hline 5 & Ячмінь & $15(0)$. & 15 (п.) & 10 (п. л.) & 10 (д. б.) \\
\hline
\end{tabular}

Примітка: *о. - оранка, п. - обробіток плоскорізом, п. л. - обробіток полицевим лущильником, д. б. - обробіток дисковою бороною 
СІЛЬСЬКЕ ГОСПОДАРСТВО. РОСЛИННИЦТВО

2. Агрохімічні властивості орного иару трунту

(у чисельнику - за 2002 рік, у знаменнику - за 2011 рік)

\begin{tabular}{|c|c|c|c|c|c|c|c|c|c|c|c|c|c|}
\hline \multirow{2}{*}{ 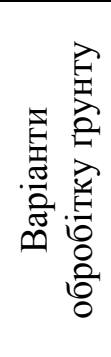 } & \multirow[t]{2}{*}{ 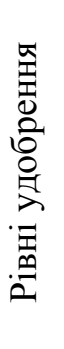 } & $\underset{\sum}{\stackrel{D}{હ}}$ & 品 & 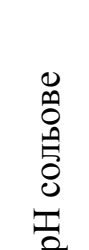 & 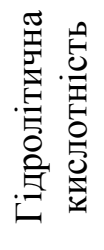 & 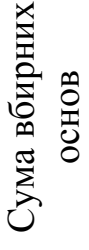 & \multirow{2}{*}{ 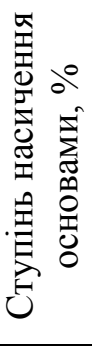 } & $0_{2}^{n}$ & $\stackrel{0}{1}$ & $\underbrace{\underbrace{+}}_{z_{1}^{+}}$ & 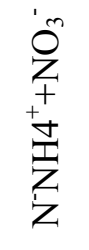 & $\stackrel{+}{\pi}$ & $\sum_{\Sigma}^{+\infty}$ \\
\hline & & \multicolumn{2}{|c|}{ т/га } & & \multicolumn{2}{|c|}{$\begin{array}{c}\text { ммоль на } \\
100 \text { г грунту }\end{array}$} & & \multicolumn{4}{|c|}{ мг/кг грунту } & \multicolumn{2}{|c|}{$\begin{array}{c}\text { ммоль на } \\
100 \text { г грунту }\end{array}$} \\
\hline \multirow{8}{*}{ 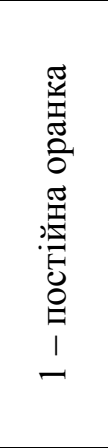 } & \multirow{2}{*}{0} & 24,8 & 10,78 & 6,14 & 2,54 & 23,4 & 90,2 & 119,4 & 76,7 & 34,3 & 41,8 & 16,83 & 2,13 \\
\hline & & 118,1 & 10,25 & 6,02 & 2,70 & 21,2 & 88,7 & 109,1 & 71,7 & 32,2 & 37,8 & 16,49 & 2,09 \\
\hline & \multirow{2}{*}{1} & 126,4 & 10,73 & 6,14 & 2,58 & 22,8 & 89,8 & 119,2 & 77,3 & 34,7 & 41,4 & 16,72 & 2,11 \\
\hline & & 124,3 & $\overline{10,49}$ & $\overline{6,00}$ & 2,82 & $\overline{20,4}$ & 87,9 & 120,7 & $\overline{78,1}$ & $\overline{34,8}$ & $\overline{42,0}$ & $\overline{16,20}$ & $\overline{2,02}$ \\
\hline & \multirow{2}{*}{2} & 123,7 & 10,75 & 6,20 & 2,60 & 23,2 & 89,9 & 117,7 & 78,0 & 33,7 & 42,2 & 16,80 & 2,12 \\
\hline & & $\overline{124,3}$ & $\overline{10,79}$ & $\overline{5,87}$ & $\overline{2,90}$ & $\overline{19,8}$ & 87,2 & 123,2 & $\overline{82,8}$ & $\overline{36,9}$ & 44,6 & $\overline{16,04}$ & 1,89 \\
\hline & \multirow{2}{*}{3} & 125,7 & 10,80 & 6,14 & 2,54 & 22,9 & 90,0 & 118,4 & 76,9 & 34, & 41,7 & 16,75 & 2,13 \\
\hline & & 7,0 & 10,90 & 5,80 & 2,97 & $\overline{19,1}$ & 86,5 & 125,7 & 85,9 & 38 & 46,9 & $\overline{15,82}$ & 1,87 \\
\hline \multirow{8}{*}{ 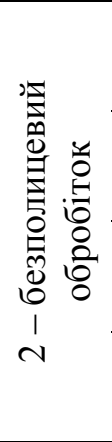 } & \multirow{2}{*}{0} & 23,7 & 10,83 & 6,14 & $\underline{2,50}$ & $\underline{23,5}$ & $\underline{90,4}$ & 117,8 & $\underline{77,4}$ & 34.4 & 42,0 & 16,69 & 2,12 \\
\hline & & 115,5 & 10,09 & 5,83 & $\overline{2,80}$ & $\overline{20,3}$ & $\overline{87,9}$ & 104,3 & $\overline{70,3}$ & $\overline{31,5}$ & $\overline{36,3}$ & $\overline{16,33}$ & 2,05 \\
\hline & \multirow{2}{*}{1} & 24,5 & 10,73 & 6,18 & 2,52 & 22,8 & 90,0 & 116,9 & 76,3 & 34,0 & 42,2 & 16,78 & 2,13 \\
\hline & & 121,0 & 10,42 & $\overline{5,75}$ & 2,88 & 19,7 & 87,2 & 115,4 & 75,6 & 33,7 & 41 & $\overline{16,08}$ & 1,98 \\
\hline & \multirow{2}{*}{2} & 125,7 & 10,84 & 6,22 & 2,58 & 22,7 & $\underline{89,8}$ & 120,1 & 76,6 & 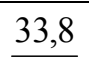 & 41,7 & $\underline{16,80}$ & 2,14 \\
\hline & & 125,8 & 10,86 & 5,64 & 2,97 & $\overline{18,4}$ & $\overline{86,1}$ & 119,8 & $\overline{80,5}$ & $\overline{36,0}$ & 43,7 & $\overline{15,91}$ & 1,87 \\
\hline & \multirow{2}{*}{3} & 123,3 & 10,80 & 6,24 & 2,49 & 23,1 & 90,3 & 117,3 & 78,2 & 34,2 & 42,4 & 16,75 & 2,12 \\
\hline & & 124,0 & 10,85 & 5,52 & 3,08 & 17,7 & 85,2 & 122,8 & 83,9 & 37,6 & 45,6 & 15,68 & 1,78 \\
\hline \multirow{8}{*}{ 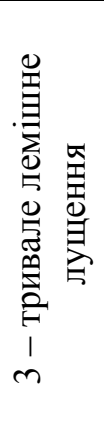 } & \multirow{2}{*}{0} & 5,9 & 0,79 & 6,1 & 2,50 & 22,7 & $\underline{90,1}$ & 118,7 & 78,0 & 34,3 & 41,5 & 16,77 & 2,12 \\
\hline & & 121,7 & 10,40 & 6,04 & 2,68 & 21,8 & 89,1 & 110,7 & 73,0 & 32,8 & 38,3 & 16,56 & 2,10 \\
\hline & & 123,2 & 10,84 & 6,18 & 2,47 & 23,0 & 90,3 & 117,5 & 77,7 & 33,9 & 41,7 & 16,81 & 2,12 \\
\hline & & 122,0 & 10,69 & 5,98 & 2,80 & 20,8 & 88,1 & 119,9 & 79,4 & 35,0 & 42 & 16,31 & 2,04 \\
\hline & \multirow[b]{2}{*}{2} & 26,8 & 10,77 & 6,15 & 2,48 & 23,2 & 90,3 & 119,4 & 76,9 & 34,4 & 42,0 & 16,82 & 2,14 \\
\hline & & 128,0 & 10,85 & 5,86 & 2,92 & 20,3 & 87,4 & 122,0 & 83,7 & 36,7 & 44,5 & 16,11 & 1,93 \\
\hline & \multirow{2}{*}{3} & 125,6 & 10,75 & 6,20 & 2,52 & 23,3 & 90,2 & 120,2 & 77,5 & 33,7 & 42,2 & 16,70 & 2,15 \\
\hline & & 127,6 & 10,92 & 5,78 & 2,98 & 19,7 & 86,9 & 125,3 & 87,0 & 38 & 47 & 15,94 & 1,90 \\
\hline \multirow{8}{*}{ 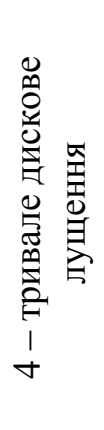 } & \multirow[b]{2}{*}{$\mathrm{C}$} & 123,4 & 10,73 & 6,14 & 2,48 & 22,5 & 90,1 & 120,0 & 76,8 & 33,5 & 41,9 & 16,80 & 2,13 \\
\hline & & 119,6 & 10,42 & 6,03 & 2,69 & 21,5 & 88,9 & 111,2 & 72,7 & 32,4 & 38,5 & 16,58 & 2,09 \\
\hline & \multirow{2}{*}{1} & 122,9 & 10,80 & 6,13 & 2,51 & 22,7 & 90,0 & 118,6 & 77,7 & 34,1 & 41,7 & 16,70 & 2,14 \\
\hline & & 122,1 & 10,68 & 6,00 & 2,82 & 20,6 & 88,0 & 121,4 & 78,8 & 34,8 & 42,4 & 16,38 & 2,04 \\
\hline & & 124,7 & 10,82 & 6,18 & 2,45 & 23,0 & 90,4 & 119,7 & 78,3 & 34,4 & 42,5 & 16,71 & 2,15 \\
\hline & 2 & 126,5 & 10,92 & 5,85 & 2,94 & 20,0 & 87,2 & 123,6 & 83,6 & 37,0 & 44,3 & 16,15 & 1,92 \\
\hline & 3 & 125,7 & 10,75 & $\underline{6,16}$ & 2,54 & 23,3 & 90,2 & 117,9 & 77,6 & 33,7 & & 16,75 & 2,13 \\
\hline & $J$ & 128,0 & 10,98 & 5,81 & 3,00 & 19,5 & 86,7 & 126,6 & 86,6 & 38,6 & 47 & 15,98 & 1,88 \\
\hline HIP & & 2,0 & 0,20 & 0,34 & 0,24 & 1,9 & 3,3 & 4,2 & 3,4 & 2,4 & 1,8 & 0,79 & 0,26 \\
\hline
\end{tabular}


Аналогічна закономірність встановлена багаторічними (1975-1984 рр.) стаціонарними дослідами на чорноземі типовому глибокому легкосуглинковому Білоцерківської дослідно-селекційної станції. Тому, як наголошують науковці, доводиться вибирати: або періодично проводити оранку і таким чином вирівнювати кислотність різних частин орного шару, або частіше здійснювати вапнування [4].

За інтенсифікації землеробства на чорноземах типових Лісостепу України для запобігання їх кислотної деградації та підвищення родючості недостатньо вносити лише органічні добрива, необхідно також застосовувати і кальційвміщуючі сполуки як меліоранти. При цьому поліпшення балансу гумусу і фізико-хімічних показників родючості чорноземів під впливом систематичного застосування органічних добрив і кальційвміщуваних речовин науковці пов'язують з оптимізацією фізичних властивостей цих грунтів [6].

I3 підвищенням рівня внесення добрив у 2011 р. спостерігалося зниження вмісту в грунті обмінних катіонів. Це пояснюється тим, що мінеральні добрива, передусім азотні, сприяють втратам кальцію і магнію 3 орного і підорного шарів грунту. Отже, підкислююча дія аміачних форм азотних добрив проявляється не тільки в їх фізіологічній кислотності, але й у посиленні процесу вимивання кальцію. Зменшення обмінних катіонів кальцію і магнію в орному шарі грунту за дві ротації сівозміни становило, відповідно: за постійної оранки - 0,64 і 0,16 ммоль/100 г; безполицевого обробітку - 0,76 і 0,21 ; тривалого лемішного лущення - 0,55 і 0,14, тривалого дискового лущення - 0,47 і 0,16 ммоль/100 г. Вміст доступних форм поживних речовин в орному шарі в 2011 р., порівняно 32002 р., зменшився за першого, третього і четвертого варіантів обробітку лише на неудобрених ділянках, а за обробітку плоскорізом - ще й на варіантах із внесенням добрив у нормі $4 \mathrm{~T} /$ га гною $+\mathrm{N}_{29} \mathrm{P}_{38} \mathrm{~K}_{38}$.

Середній вміст $\mathrm{P}_{2} \mathrm{O}_{5}, \mathrm{~K}_{2} \mathrm{O}, \mathrm{N}-\mathrm{NH}_{4}{ }^{+}$i N- $\mathrm{NH}_{4}{ }^{+}+$ $\mathrm{N}-\mathrm{NO}_{3}{ }^{-}$зріс за найвищого рівня внесених добрив в орному шарі за 10 років, відповідно: за постійної оранки - на 7,3; 9,0; 4,3 і 5,2 мг/кг; безполицевого обробітку $-5,5 ; 5,7 ; 3,4$ і 3,2 ; тривалого лемішного лущення - 5,1; 9,5; 4,8 і 4,8; тривало-

\section{БІБЛІОГРАФІЯ}

1. Грищаєнко 3. М. Методи біологічних та агрохімічних досліджень рослин і грунтів / [Грицаєнко 3. М., Грицаєнко А. О., Карпенко В. П. ] - К. : ЗАТ «Нічлава», 2003. - $320 \mathrm{c}$.

2. Екологічні проблеми землеробства / Примак I. Д., го дискового лущення $-8,7 ; 9,0 ; 4,9$ і 5,1 мг/кг грунту.

Якщо за тривалого полицевого обробітку елементи азотного і зольного живлення рослин розподілялися порівняно рівномірно по всьому орному шарі, то за тривалого мілкого - й особливо плоскорізного обробітку - спостерігалась їх локалізація у верхній (0-10 см) частині орного шару.

Встановлено, що проведення лише один раз за ротацію сівозміни глибокої оранки (3 і 4 варіанти) усуває гетерогенність на 1,5-2 роки. На день сівби пшениці озимої уже простежувалася диференціація орного шару за вмістом рослинних решток і доступних форм елементів живлення. За безполицевого обробітку зменшення вихідного вмісту в орному шарі доступних форм елементів живлення в 2011 р. зафіксовано не тільки на неудобрених ділянках, але й за внесення на 1 га ріллі 4 т гною $+\mathrm{N}_{29} \mathrm{P}_{38} \mathrm{~K}_{38}$.

За десятирічний період досліджень зниження вмісту $\mathrm{Ca}^{2+}$ на неудобрених ділянках і за внесення 12 т гною $+\mathrm{N}_{87} \mathrm{P}_{114} \mathrm{~K}_{114}$ становило, відповідно: за постійної оранки $-0,34$ і 0,93 ммоль/100 г грунту; безполицевого обробітку - 0,36 і 1,07; тривалого лемішного лущення - 0,21 і 0,76; тривалого дискового лущення - 0,22 і 0,77 ммоль/100 г грунту.

Продуктивність сівозміни за тривалого мілкого обробітку була на рівні контролю, а за безполицевого - істотно нижчою. Збір сухої речовини на 5-7 ц/га нижчий за другого, ніж контрольного варіанта обробітку.

\section{Висновки:}

1. Статистично достовірне зростання вмісту гумусу за дві ротації сівозміни відмічене лише за найвищого рівня внесення добрив і тривалого мілкого обробітку.

2. Кращі агрохімічні показники родючості орного шару спостерігаються за тривалого мілкого обробітку, порівняно 3 постійним полицевим i безполицевим.

3. Систематичний безполицевий обробіток, порівняно 3 постійною оранкою, призводить до зниження продуктивності сівозміни. Продуктивність сівозміни за постійної оранки й тривалого мілкого обробітку залишається практично на одному рівні.

Манько Ю. П., Рідей Н. М. [та ін.]; за ред. І. Д. Примака. - К. : Центр учбової літератури, 2010. $-456 \mathrm{c}$.

3. Сщенко В. О. Мінімалізація механічного обробітку грунту при вирощуванні кукурудзи / 
[Єщенко В. О., Каричковський В. Д., Сщенко О. В.] - Умань, 2007. - 157 с.

4. Зубенко В. Ф. Урожайность культур и баланс элементов питания в свекловичных севооборотах при разных дозах удобрений и способах обработки почвы / Зубенко В. Ф., Якименко В. Н., Лютая Ю. А. [и др.]. - Вестник сельськохозяйственной науки, 1986, № 11. - С. 50-59.

5. Медведев В. В. Почвенно-технологическое районирование пахотных земель Украины / [Медведев В. В., Лактионова Т. Н.] - Х. : Изд-во «13 типография», 2007. - $395 \mathrm{c}$.

6. Медведев B. B. Структура почвы (методы, генезис, классификация, эволюция, география, мониторинг, охрана). - Х. : Изд-во «13 типография», 2008. - $406 \mathrm{c.}$

7. Охорона грунтів / Шикула М. К., Гнатенко О. Ф., Петренко Л. Р. [та ін.] - К. : Т-во «Знання». 2004. $-398 \mathrm{c}$.

8. Ресурсозберігаючі технології механічного обробітку грунту в сучасному землеробстві України / І. Д. Примак, В. О. Сщенко, Ю. П. Манько [та ін.] за ред. І. Д. Примака. - К. : КВІЦ, 2007. $272 \mathrm{c}$.

9. Сайко В. Ф. Системи обробітку грунту в Україні / В. Ф. Сайко, А. М. Малієнко. - К. : ВД «ЕКMO», 2007. - 44 c. 